\title{
Mens man venter på turnusplass ...
}

\author{
Turnustjenesten er en nyttig og ønsket ordning, men kapasiteten i ordningen er ikke \\ dimensjonert for antallet søkere. Dermed oppstår det ventelister, og nyutdannede leger \\ spør seg: Hva kan jeg gjøre mens jeg venter?
}

\section{Jon Ole Whist}

jon.ole.whistalegeforeningen.no

Den norske legeforening

Postboks 1152 Sentrum

0107 Oslo

Alt helsepersonell i Norge er avhengig av autorisasjon for å utøve sitt virke. Dette er regulert i helsepersonelloven $\S 48$ (1). I Norge er utgangspunktet at leger får autorisasjon etter fullført og godkjent turnustjeneste. Helsepersonelloven $\S 49$ åpner for at helsepersonell som ikke har rett til autorisasjon, etter søknad kan gis lisens. Dette er nærmere regulert i egen forskrift (2). Både autorisasjon og lisens utstedes av Statens autorisasjonskontor for helsepersonell (SAFH). Forskriften regulerer lisens til medisinstudenter og turnuslisens. I tillegg er det en rekke administrativt innførte lisenser som fremgår av SAFHs nettsider (3), herunder lisens til cand.med. uten avtjent turnustjeneste.

\section{Studentlisens}

Kravene for å få tildelt studentlisens er at studenter ved norske universiteter har fullført minst $41 / 2$ år av studiet med normal progresjon. Studenten må ha avlagt eksamen i 9. semester og kan få lisens i påvente av sensuren. Lisensen bortfaller imidlertid dersom sensuren viser at studenten ikke har bestått, kfr. forskriftens $\S 5$ tredje ledd (2). Det er videre et krav at studenten har fått obligatorisk teoretisk og praktisk undervisning i de kliniske hovedfagene generell indremedisin og kirurgi, allmennmedisin, gynekologi og obstetrikk, pediatri og psykiatri. I tillegg må studenten ha mottatt teoretisk og praktisk undervisning i farmakologi og reseptlære. Studenter ved utenlandske universiteter kan få lisens når de har gjennomført eksamen i alle prekliniske fag og som hovedregel ikke har mer enn ett år igjen til avsluttende eksamen.

Student med lisens kan ikke kalle seg lege, men kan benytte tittelen stud.med. Studentlisensen gir adgang til å arbeide ved sykehus eller annen helseinstitusjon eller som assistent hos privatpraktiserende lege. Lisensen gir ikke adgang til å utøve lege- virksomhet av selvstendig karakter. Studentlisens gir kun rett til å forskrive legemidler i gruppe $\mathrm{B}$ og $\mathrm{C}$ i arbeidssammenheng. Studenten har altså ikke adgang til å forskrive legemidler utenfor arbeid.

Studenten kan ikke være vikar for lege, ikke delta i legevakt og ikke fungere som bakvakt. For studenter som arbeider hos offentlig eller privatpraktiserende lege, er det en forutsetning at de arbeider i nær tilknytning til en praktiserende lege. Denne veiledningen og oppfølgingen bør formaliseres skriftlig i en assistentavtale. Lisensen gir ikke studenten adgang til å sende regning til trygden for legehjelp, men refusjonskrav kan føres på regningskortet til den praktiserende legen som veileder studenten. Man bør på forhånd avklare opplegget med Helfo (4) for å unngå overraskelser når det gjelder utbetaling av refusjon. Legeforeningen jobber for tiden med en veileder for situasjoner hvor privatpraktiserende leger har inngått eller planlegger å inngå en assistentavtale med medisinstudenter med lisens eller cand.med.-er med lisens. Veilederen vil bli publisert på Legeforeningens nettsider.

Det har imidlertid vært lang praksis for at norske sykehus har ansatt studenter med lisens i forbindelse med sommerferieavviklingen. Arbeidsgiver er ansvarlig for forsvarlig organisering av arbeidet innenfor de rammer lisensen setter. I forsvarlighetsvurderingen må det bl.a. vurderes om studenten har nødvendige medisinske kvalifikasjoner til å håndtere de situasjonene som kan tenkes å oppstå. Studenten har selvsagt også et personlig ansvar for å kjenne sine faglige begrensninger og dermed yte for- svarlig helsehjelp etter helsepersonelloven $\S 4$ (1). Det er bedre å tilkalle bistand én gang for mye enn én gang for lite.

Søknadsskjema og nærmere informasjon om studentlisens og cand.med. med lisens finnes på nettsidene til SAFH (3).

\section{Turnuslisens}

For å få tildelt turnuslisens må man ha oppnådd graden cand.med. eller ha fătt sin utenlandske eksamen anerkjent som faglig jevngod med norsk cand.med.-grad. Videre må man være påmeldt til turnustjeneste og ha fått turnussted anvist av Statens autorisasjonskontor for helsepersonell. Turnuslisensen utstedes automatisk og skal bli utdelt til turnuskandidatene ved oppstart på turnussykehuset.

Innholdet i turnustjenesten er regulert i egen forskrift om praktisk tjeneste (turnustjeneste) for å få autorisasjon som lege (5), der det i $§ 1$ står: «Formålet med den praktiske tjenesten (turnustjenesten) er at turnuslegen gjennom arbeid som lege under særskilt veiledning, opplæring og supervisjon skal få nødvendig erfaring, herunder erfaring med akutte tilstander, samt tilegne seg praktisk rutine for selvstendig å kunne utføre vanlig legevirksomhet på forsvarlig måte. Den praktiske tjenesten skal tilrettelegges på forsvarlig måte og utføres i tråd med gjeldende regelverk og i samsvar med målbeskrivelse fastsatt av Sosial- og helsedirektoratet.»

I målbeskrivelsen for turnustjenesten (6) fremgår det at turnuslegen «tjenestegjør i underordnet legestilling med i hovedsak de samme rettigheter og plikter som gjelder for leger for øvrig, men slik at turnuslegen
Tabell 1 Minimumslønn per 1.3. 2010 for studenter med lisens, cand.med.-er med lisens og turnusleger
KS

Oslo kommune

Spekter-område 10

Lovisenberg Diakonale

Sykehus

$\mathrm{HSH}$
Stud.med. med lisens

\section{Kr 378000}

Ltr. 40 (kr 373 100)

Kr 353500

$\mathrm{Kr} 341800$

Kr 340500
Cand.med. med lisens Turnuslege

Kr $378000 \quad \mathrm{Kr} 378000$

Ltr. 40 (kr 373 100) Ltr. 40 (kr 373 100)

Kr $390000 \quad$ Kr 390000

Ikke regulert Kr 376000

Kr $376000 \quad$ Kr 376000 
arbeider under tilsyn, veiledning og supervisjon av overordnede leger». Turnusleger har bl.a. full forskrivningsrett og adgang til å delta i legevakt. Turnusleger kan ikke praktisere selvstendig for trygdens regning. Turnustjenesten er imidlertid en veiledet tjeneste. Derfor vil turnusleger kunne sende inn regningskort i eget navn for det arbeidet som gjøres på legevakt.

\section{Cand.med. med lisens}

Som tidligere nevnt er cand.med. med lisens ikke særskilt omtalt i forskriften. Avgjørende for hvilke oppgaver man da kan påta seg, er lisensdokumentets formulering og forbehold. Formuleringene i de ordinære lisenser til stud.med. og cand.med. er så å si identiske, slik at en cand.med. med lisens i alle praktiske henseender må anses å ha de samme begrensningene som en med stud.med.-lisens. Legeforeningen har overfor Helsedirektoratet anført at en cand.med. med lisens må kunne dekke kommunale legevaktsoppgaver like godt som en turnuslege, men dette er det for tiden ikke åpnet opp for.

\section{Lønnsvilkår}

Ved ansettelse hos offentlige arbeidsgivere er det avtalt i overenskomstene/tariffavtalene hvilken minimumslønn studenter med lisens, cand.med.-er med lisens og turnusleger skal ha (tab 1). Tabellen angir minstelønnssatser, og det er full adgang til å avtale høyere avlønning. I tilfeller der arbeidsbehovet som skal dekkes skyldes fraværet av en lege i spesialisering, vil dette kunne være et argument for å be om å bli avlønnet som slik.

Studenter og cand.med.-er med lisens som skal arbeide privat har full avtalefrihet.

\section{Refusjon fra trygden}

Selvstendig refusjonsrett får man først etter tre års veiledet tjeneste. Det anses å ligge 0,5 års praktisk tjeneste i studiet. Når dette legges til 1,5 år turnustjeneste gjenstår ett år i veiledet tjeneste etter turnus og oppnådd autorisasjon. For leger som går rett ut i allmennpraksis etter endt turnustjeneste, er dette særlig viktig å være oppmerksom på. Det er kommunen som har ansvar for å skaffe veileder og for å avlønne denne.

\section{Litteratur}

1. Lov om helsepersonell. LOV-1999-07-02-64.

2. Forskrift om lisens til helsepersonell. FOR 200012-21 nr 1379

3. Statens autorisasjonskontor for helsepersonell. www.safh.no (23.3.2010).

4. Helseøkonomiforvaltningen. www. helfo.no (23.3.2010).

5. Forskrift om praktisk tjeneste (turnustjeneste) for å få autorisasjon som lege (FOR 2001-12-20 nr 1549).

6. Vedlegg 1 i Rundskriv IS-9/2005 fra Helse- og sosialdirektoratet. Oslo: Helse- og sosialdirektoratet, 2005 .

Manuskriptet ble mottatt 23.3. 2010 og godkjent 8.4. 2010. Medisinsk redaktør Petter Gjersvik. 